\title{
PENGARUH KOMITMEN ORGANISASI DAN PENEMPATAN KERJA TERHADAP KINERJA KARYAWAN PADA KANTOR BADAN PUSAT STATISTIK PROVINSI SUMATERA UTARA
}

\author{
Helen Ferananda Habeahan \\ Alumni Jurusan Manajemen Fakultas Ekonomi Universitas Negeri Medan \\ Hilma Harmen \\ Dosen Jurusan Manajemen Fakultas Ekonomi Universitas Negeri Medan
}

\begin{abstract}
Abstrak
Penelitian ini bertujuan untuk mengetahui seberapa besarpengaruh Komitmen Organisasi dan Penempatan Kerja terhadap Kinerja Karyawan pada Kantor Badan Pusat Statistik Provinsi Sumatera Utara. Metode yang digunakan dalam penelitian ini adalah analisis regresi berganda yang bertujuan untuk mengukur hubungan antar variabel bebas dan variabel terikat. Jumlah populasi dalam penelitian ini adalah 101 orang dengan sampel yang diambil adalah sebanyak 81 orang dengan menggunakan Total Sampling. Teknik analisis data yang digunakan adalah uji normalitas, uji heterokedastisitas, uji multikolonieritas, dan analisis regresi berganda. Analisis data masing-masing variabel diperoleh persamaan regresi berganda $\boldsymbol{Y}=31,471+0,245 \mathrm{X}_{1}+$

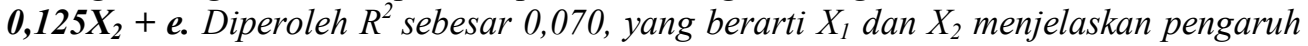
terhadap variabel $Y$ sebesar $7 \%$ sedangkan sisanya dijelaskan variabel diluar perusahaan. Uji parsial yang dihasilkan masing-masing variabel bebas berpengaruh terhadap variabel terikat dengan signifikansi penelitian lebih kecil dari 0.05, serta hasil perhitungan uji-simultan sebesar 3,929dengan $F_{\text {tabel }}$ 3,11yang artinya $F_{\text {hitung }}>F_{\text {tabel }}$ dengan taraf signifikan $(\alpha)<0,05$, yang artinya hipotesis diterima yaitu Komitmen Organisasi dan Penempatan Kerjasecara bersama-sama berpengaruh signifikan terhadap Kinerja karyawan pada Kantor Badan Pusat Statistik Provinsi Sumatera Utara.
\end{abstract}

Kata kunci : Komitmen Organisasi, Penempatan Kerja, Kinerja Karyawan

\section{PENDAHULUAN}

Setiap organisasi memiliki tujuan yang harus dicapai dalam operasionalnya. Dalam pencapaian tujuan tersebut, sumber daya manusia memegang peranan yang paling penting, karena sumber daya manusia merupakan perencana, pelaku aktif, dan pengendali setiap aktivitas yang dilakukan organisasi atau instansi dalam mencapai tujuan. Sumber daya manusia baik yang menduduki posisi pimpinan maupun anggota merupakan faktor terpenting dalam setiap organisasi atau instansi baik pemerintah maupun swasta. Hal ini karena berhasil tidaknya suatu organisasi sebagian besar dipengaruhi oleh faktor manusia selaku pelaksana pekerjaan. Organisasi merupakan suatu kumpulan orang-orang yang saling bekerjasama dengan memanfaatkan fasilitas yang ada untuk mencapai tujuan yang telah direncanakan.

Organisasi dan karyawan merupakan dua hal yang saling membutuhkan, jika karyawan berhasil membawa kemajuan bagi perusahaan, keuntungan yang diperoleh akan dipetik oleh kedua belah pihak. Bagi karyawan, keberhasilan merupakan 
aktualisasi diri sekaligus peluang untuk memenuhi kebutuhan hidupnya. Sedangkan bagi organisasi atau instansi, keberhasilan merupakan sarana menuju pertumbuhan dan perkembangan organisasi itu sendiri.

Karyawan memiliki peran yang besar dalam kesuksesan perusahaan. Tolak ukur keberhasilan suatu perusahaan dapat dilihat dari kinerja karyawan. Kinerja karyawan berarti produktifitas dan output karyawan sebagai hasil dari pengembangan karyawan, dan akhirnya mempengaruhi efektivitas perusahaan (Hammed dan Waheed 2011:228).

Organisasi atau instansi dituntut untuk selalu meningkatkan kinerja karyawan agar perusahaan atau instansi dapat terus berkembang. Karena dengan adanya peningkatan kinerja dalam diri karyawan, maka karyawan mampu mengoptimalkan kemampuan untuk melakukan pekerjaannya. Kinerja karyawan yang maksimal merupakan aset yang tak ternilai bagi organisasi atau instansi, maka dari itu setiap organisasi akan selalu berusaha untuk meningkatkan kinerja karyawan dengan harapan apa yang menjadi tujuan organisasi atau instansi akan tercapai. Kinerja karyawan yang baik dapat dicapai melalui penanaman komitmen organisasi yang kuat dalam diri karyawan dan penempatan kerja karyawan yang cocok dengan potensi karyawan.

Komitmen organisasi menentukan berhasil atau tidaknya tujuan yang ingin dicapai oleh organisasi atau instansi. Dengan adanya komitmen karyawan terhadap suatu organisasi atau instansi, dapat membuat karyawan tersebut memiliki rasa tanggung-jawab yang besar dan bersedia memberikan segala kemampuannya, sehingga timbul rasa memiliki terhadap organisasi atau instansi tempat ia bekerja. Sebab komitmen karyawan yang tinggi terhadap organisasi memungkinkan seseorang karyawan memperlihatkan keinginan yang kuat untuk tetap menjadi anggota organisasi atau instansi, kemudian karyawan tersebut bersedia untuk berusaha sebaik mungkin demi kepentingan organisasi tersebut serta tingkat kepercayaan yang tinggi akan tujuan dan nilai-nilai organisasi atau instansi yang melekat pada dirinya.

Keberhasilan suatu organisasi akan berdampak pada kelangsungan hidup organisasi dan karyawannya. Dengan demikian, apabila masingmasing karyawan dalam organisasi atau instansi memiliki komitmen yang tinggi terhadap organisasi, maka besar kemungkinan kesuksesan dapat tercapai dan sebaliknya, apabila masing-masing karyawan tidak memiliki komitmen yang tinggi atau komitmen yang rendah, maka besar kemungkinan kesuksesan tidak dapat tercapai secara maksimal.

Komitmen organisasi tidak hanya berpatokan pada tanggungjawab dan loyalitas karyawan terhadap organisasi atau instansinya, namun bagaimana karyawan merasa aman dan nyaman ketika menjadi bagian dalam organisasi yang ditempati. Komitmen organisasi terdiri dari komitmen karyawan terhadap organisasi dan komitmen organisasi terhadap karyawan. Komitmen memiliki peranan penting terutama pada kinerja seseorang ketika bekerja. Hal ini disebabkan oleh adanya komitmen yang menjadi acuan serta dorongan yang membuat 
mereka lebih bertanggung-jawab terhadap kewajibannya.

Dengan kata lain, hal ini dapat dianggap sebuah pola pikir dimana karyawan memikirkan sejauh mana nilai dan tujuannya sendiri sesuai dengan tujuan organisasi atau instansi tempat ia bekerja. Adanya kesesuaian antara nilai dan tujuan karyawan dengan organisasi akan menumbuhkan komitmen yang kuat dalam diri karyawan dalam bekerja di organisasi sehingga menyebabkan terjadinya tingkah laku karyawan yang sesuai dengan harapan organisasi. Maka untuk membangkitkan komitmen karyawan tersebut, organisasi harus memperhatikan faktor-faktor yang mempengaruhi komitmen berorganisasi yaitu: karakteristik organisasi menyangkut kebijakan dan aturan dalam organisasi atau instansi, karakteristik individu menyangkut tentang kebutuhan berprestasi karyawan serta pengalaman kerja karyawan menyangkut tentang motivasi dan cara kerja karyawan. Perusahaan penting memperhatikan faktor-faktor komitmen organisasi, dimaksudkan agar perusahaan selalu dapat menumbuhkan dan membina kepercayaan karyawan terhadap organisasi atau instansi.

Penempatan kerja juga menentukan berhasil atau tidaknya tujuan yang ingin dicapai oleh organisasi atau instansi. Dalam mewujudkan eksistensinya, organisasi atau instansi memerlukan sejumlah karyawan yang terarah pada pencapaian tujuan yang telah ditetapkan. Penempatan karyawan yang memenuhi kualifikasi dan didukung dengan organisasi yang berkualitas, akan menjadikan organisasi atau instansi tersebut memiliki daya kompetitif yang tinggi. Penempatan karyawan itu sendiri dimulai kegiatan rekrutmen dan seleksi. Aktivitas rekrutmen dan seleksi yang berkualitas akan menunjukkan orang yang terbaik untuk jabatan yang tersedia dan memastikan orang tersebut ditempatkan pada posisi yang tepat.

Pada dasarnya, penempatan merupakan pengisian jabatan yang kosong agar tugas pokok pada jabatan tersebut dapat dilaksanakan dengan baik. Karyawan yang ditempatkan sesuai pada bidang kemampuannya dapat memicu kinerjanya dalam bekerja dan meningkatkan ketrampilannya. Keberhasilan dalam melakukan penempatan tenaga kerja akan banyak mempengaruhi langkah selanjutnya dalam proses pencapaian tujuan organisasi atau instansi. Dengan kata lain, karyawan yang ditempatkan tersebut memiliki kemampuan untuk dapat melaksanakan pekerjaannya pada suatu jabatan secara efektif dan efisien sehingga diharapkan menghasilkan karyawan yang berprestasi demi mewujudkan misi organisasi atau instansi.

Penempatan harus didasarkan pada job description dan job specification yang telah ditentukan serta berpedoman kepada prinsip "The right man on the right place and the right man behind the job". Hal ini akan membawa suatu instansi kepada hasil kerja yang optimal karena terdapat adanya korelasi positif antara penempatan pegawai dengan peningkatan produktifitas kerja (Hasibuan, 2005:63). 


\section{METODE PENELITIAN \\ Lokasi Penelitian}

Penelitian ini dilaksanakan di Kantor Badan Pusat Statistik (BPS) Provinsi Sumatera Utara yang beralamat di Jalan Asrama No. 179, Medan (20123) Sumatera Utara, Indonesia.

\section{Populasi dan Sampel}

Menurut Kuncoro (2013:118)

"Populasi adalah kelompok elemen yang lengkap, yang biasanya berupa orang, objek, transaksi, atau kejadian dimana kita tertarik untuk mempelajarinya atau menjadi objek penelitian.

Jumlah populasi dalam penelitian ini adalah seluruh karyawan pada Kantor Badan Pusat Statistik (BPS) Provinsi Sumatera Utara yang berjumlah 101 orang,

Teknik pengambilan sampel yang digunakan dalam penelitian adalah teknik total sampling yaitu teknik pengambilan sampel dimana setiap anggota populasi dijadikan sampel. Dalam pemilihan sampel tersebut, seluruh kepala seksi dan staf karyawan Badan Pusat Statistik Provinsi Sumatera Utara akan dijadikan sampel, dan khusus bagian Bina Program dan Bagian Urusan Dalam tidak dijadikan sampel. Maka total sampel yang diambil adalah berjumlah 81 orang.

\section{Teknik Analisis Data}

\section{Analisis Regresi Berganda}

Setelah data berskala interval, untuk mengetahui bagaimana pengaruh antara 2 variabel bebas $X_{1}$, $\mathrm{X}_{2}$ (komitmen organisasi dan penempatan kerja) terhadap variabel Y (Kinerja karyawan) digunakan teknik data dengan menggunakan rumus analisis statistic regresi berganda sebagai berikut:

$$
\mathbf{Y}=\mathbf{a}+\mathbf{b}_{1} \mathbf{X}_{1}+\mathbf{b}_{2} \mathbf{X}_{2}+\mathbf{e}
$$

Keterangan :

$\mathrm{Y}=$ Kinerja Karyawan

a $\quad$ Konstanta

$\mathrm{b}_{1} \quad=$ Koefisien Komitmen Organisasi

$\mathrm{b}_{2} \quad=$ Koefisien Penempatan Kerja

$\mathrm{X}_{1}=$ Komitmen Organisasi

$\mathrm{X}_{2}=$ Penempatan Kerja

e $\quad=$ Standar error

\section{Uji Hipotesis}

Uji F (Simultan)

Yaitu pengujian regresi secara simultan atau serentak antara variabel independen terhadap variabel dependen. Dimana $F_{\text {hitung }}>F_{\text {tabel }}$, maka $\mathrm{H}_{1}$ diterima dan menolak $\mathrm{H}_{0}$ atau secara bersama-sama variabel bebas dapat menerangkan variabel terikatnya secara serentak. Sebaliknya apabila $F_{\text {hitung }}>F_{\text {tabel, }}$ maka Ho diterima dan menolak $\mathrm{H}_{1}$ atau secara bersama-sama variabel bebas tidak memiliki pengaruh terdapat variabel terikat. Untuk mengetahui signifikan atau tidak pengaruh secara bersamasama variabel bebas terhadap variabel terikat maka digunakan probability sebesar $5 \%(\alpha=0,05)$.

- Jika tingkat signifikan i $>\alpha$ $(0,05)$, maka $\mathrm{H}_{0}$ diterima $\mathrm{H}_{1}$ ditolak.

- Jika tingkat signifikan $\mathrm{i}<\alpha$ $(0,05)$, maka $\mathrm{H}_{0}$ ditolak $\mathrm{H}_{1}$ diterima.

\section{Uji t (Parsial)}

Uji statistik $t$ pada dasarnya menunjukkan seberapa jauh pengaruh satu variabel independen secara individual dalam menerangkan variabel dependen. Dasar pengambilan keputusan ditentukan dengan cara sebagai berikut: 
- Jika tingkat signifikansi $\mathrm{t}_{\text {hitung }}<$ 0,05 atau $t_{\text {hitung }}>t_{\text {tabel }}$, maka $\mathrm{H}_{1}$ diterima

- Jika tingkat signifikansi $t_{\text {hitung }}<$ 0,05 atau $t_{\text {hitung }}>t_{\text {tabel }}$, maka $\mathrm{H}_{0}$ ditolak

\section{Koefisien Determinasi $\left(\mathbf{R}^{2}\right)$}

Uji ini dilakukan untuk mengukur seberapa besar pengaruh yang diberikan variabel bebas terhadap variabel terikat. Jika $\mathrm{R}^{2}$ semakin mendekati satu, maka pengaruh variabel bebas terhadap variabel terikat mempunyai pengaruh yang besar, dan sebaliknya apabila $\mathrm{R}^{2}$ semakin mendekati nol, maka pengaruh variabel bebas terhadap variabel terikat mempunyai pengaruh yang kecil.

\section{HASIL PENELITIAN DAN PEMBAHASAN \\ Hasil Penelitian}

Model Regresi Berganda dengan satu variabel dependent (Y) yaitu Kinerja Karyawan dan 2 variabel Independent (X1) yaitu Komitmen Organisasi dan (X2) yaitu Penempatan Kerja dirumuskan sebagai berikut.

$$
\mathbf{Y}=\mathbf{a}+\mathbf{b}_{\mathbf{1}} \mathbf{X}_{\mathbf{1}}+\mathbf{b}_{\mathbf{2}} \mathbf{X}_{\mathbf{2}}+\mathrm{e}
$$

Untuk menguji hipotesis yang menyatakan terdapat pengaruh Komitmen Organisasi (X1) dan Penempatan Kerja (X2) terhadap Kinerja Karyawan (Y) digunakan analisis regresi berganda.

Dari hasil SPSS dapat dijelaskan sebagai berikut :

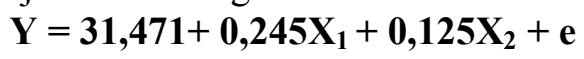

1. Konstanta sebesar 31,471menyatakan bahwa jika tidak ada variabel $\mathrm{X}$, yaitu Komitmen Organisasi dan Penempatan Kerja maka Kinerja
Karyawan adalah sebesar 31,471 dengan asumsi faktor lain konstan.

2. Koefisien X1 sebesar 0,245 menyatakan bahwa setiap terjadi peningkatan Komitmen Organisasiakan mempengaruhi Kinerja Karyawan sebesar 0,245dengan asumsi faktor lain konstan.

3. Koefisien X2 sebessar 0,125 menyatakan bahwa setiap terjadi peningkatan Penempatan Kerjaakan mempengaruhi Kinerja Karyawan sebesar 0,125dengan asumsi faktor lain konstan.

Uji Hipotesis

Pengujian Hipotesis Secara Parsial Menggunakan Uji t

Uji $t$ dilakukan untuk mengetahui pengaruh Komitmen Organisasi dan Penempatan Kerja secara parsial atau individu terhadap Kinerja Karyawan. Dari hasil SPSS maka dapat dijelaskan bahwa :

a. Nilai $t_{\text {hitung }}$ variabel Komitmen Organisasi2,389>dari $t_{\text {tabel }}$ yaitu 1,664 (lihat tabel $t$ dalam lampiran) dan nilai signifikan $0.019<0,05$ Hal ini berarti hipotesis diterima yaitu: Komitmen Organisasi secara parsial berpengaruh positif dan signifikan terhadap Kinerja Karyawanpada Kantor Badan Pusat Statistik Provinsi Sumatera Utara.

b. Nilai $t_{\text {hitung }}$ variabel Penempatan Kerja 1,725> dari $t$ tabel yaitu 1.664 dan nilai signifikan $0.001<$ 0,05 . Hal ini berarti hipotesis diterima yaitu: Penempatan Kerja secara parsial berpengaruh positif dan signifikan terhadap kinerja 
Karyawan pada Kantor Badan Pusat Statistik Provinsi Sumatera Utara.

\section{Pengujian Hipotesis Secara Simultan Menggunakan Uji F}

Uji Simultan atau Uji F merupakan Uji secara bersama-sama untuk menguji signifikan pengaruh variabel Komitmen Organisasi dan Penempatan Kerja terhadap Kinerja Karyawan.

Berdasarkan hasil pengujian statistik (Uji Anova/Uji F) Dapat dilihat pada tabel output berikut :

Tabel 1. Hasil Uji F ANOVA $^{b}$

\begin{tabular}{|l|c|r|r|r|r|}
\hline Model & $\begin{array}{c}\text { Sum of } \\
\text { Squares }\end{array}$ & Df & $\begin{array}{c}\text { Mean } \\
\text { Square }\end{array}$ & F & Sig. \\
\hline 1 Regression & 291.588 & 2 & 145.794 & 3.929 & $.001^{\text {a }}$ \\
Residual & 3883.188 & 78 & 49.784 & & \\
Total & 4174.776 & 80 & & & \\
\hline
\end{tabular}

a. Predictors: (Constant), PENEMPATAN KERJA, KOMITMEN ORGANISASI

b. Dependent Variable:

KINERJA KARYAWAN

Pada tabel diatas diperoleh bahwa nilai $F_{\text {hitung }}=3,929$ dengan tingkat signifikansi $\mathbf{0 , 0 0 1}<\mathbf{0 , 0 5}$.F tabel dapat dilihat pada tabel statistik (Terlampir) pada tingkat signifikansi 0,05 dengan $\mathrm{df} 1$ (Jumlah variabel) $=$ 2 , dan df $2(\mathrm{n}-\mathrm{k}-1)$ atau $81-2-1=$ 78. Setelah mengetahui $F_{\text {hitung, maka }}$ akan di bandingkan dengan $F_{\text {tabel }}$ dengan taraf kesalahan $5 \%$ adalah $=$ 3,11 maka $F_{\text {hitung }}=3,929>F_{\text {tabel }}(3,11)$. Dengan demikian, bahwa koefisien arah regresi berganda pada taraf signifikan 0.05 menyatakanKomitmen Organisasi dan Penempatan Kerja secara bersama-sama atau simultan berpengaruh positif dan signifikan terhadap Kinerja Karyawan pada Kantor Badan Pusat Statistik Provinsi Sumatera Utara.

\section{Koefisien Determinasi ( $\mathbf{R}^{\mathbf{2}}$ )}

Untuk mengetahui seberapa besar Persentase Pengaruh variabel bebas terhadap variabel terikat atau untuk melihat seberapa besar variabel bebas dapat menjelaskan pengaruhnya terhadap variabel terikat. Maka dilakukan pengujian koefisien determinasi $\left(\mathrm{R}^{2}\right)$ sehingga di peroleh hasil seperti tabel di bawah ini.

Tabel 2. Hasil Uji Koefisien Determinasi $\left(\mathbf{R}^{2}\right)$ Model Summary ${ }^{\mathrm{b}}$

\begin{tabular}{|l|c|r|r|r|}
\hline Model & $\mathrm{R}$ & $\begin{array}{c}\mathrm{R} \\
\text { Square }\end{array}$ & $\begin{array}{c}\text { Adjusted R } \\
\text { Square }\end{array}$ & $\begin{array}{l}\text { Std. Error of } \\
\text { the Estimate }\end{array}$ \\
\hline 1 & $.264^{\mathrm{a}}$ & .070 & .046 & 7.056 \\
\hline
\end{tabular}

KERJA, KOMITMEN ORGANISASI

b. Dependent Variable: KINERJA KARYAWAN

Dari tabel output diatas dapat dilihat bahwa koefisien determinan $\left(\mathrm{R}^{2}\right)$ adalah sebesar 0,070 . Nilai ini menunjukan bahwa variabel Kinerja Karyawan (Y) dipengaruhi oleh variabel Komitmen Organisasi $\left(\mathrm{X}_{1}\right)$ Dan Penempatan Kerja $\left(\mathrm{X}_{2}\right)$ secara bersama-sama sebesar 7,0\% dan sisanya dipengaruhi oleh variabel lain yang tidak dibahas dalam penelitian ini.

\section{Pembahasan Hasil Penelitian Hasil Penelitian Variabel Komitmen Organisasi (X1)}

Dengan melihat hasil penelitian yang dilakukan, diperoleh pengujian hipotesis Komitmen Organisasi terhadap Kinerja Karyawan menghasilkan $t_{\text {hitung }}>t_{\text {tabel }}$ sebesar 2,389 $>1,664$ dengan nilai signifikan $0.019<0,05$. Selain itu, hasil penelitian menunjukkan nilai koefisien regresi sebesar 0,245. Sehingga dapat diartikan bahwa pada taraf signifikan 5\%, Komitmen 
Organisasi memiliki pengaruh positif dan signifikan terhadap Kinerja Karyawan.

\section{Hasil Penelitian Variabel Penempatan Kerja (X2)}

Dengan melihat hasil penelitian yang dilakukan, diperoleh pengujian hipotesis Penempatan Kerja terhadap Kinerja Karyawan menghasilkan $t_{\text {hitung }}>t_{\text {tabel }}$ sebesar $1,725>1,664$ dengan nilai signifikan $0.001<0,05$. Selain itu, hasil penelitian menunjukkan nilai koefisien regresi sebesar 0,125. Sehingga dapat diartikan bahwa pada taraf signifikan 5\%, Penempatan Kerja memiliki pengaruh positif dan signifikan terhadap Kinerja Karyawan.

Dengan demikian, semakin baik Penempatan Kerja didalam perusahaan maka akan semakin tinggi pengaruhnya terhadap Kinerja karyawan, sehingga akan memberikan pengaruh yang lebih baik untuk perusahaan.

\section{Hasil Penelitian Variabel Kinerja Karyawan (Y)}

Dengan melakukan hasil penelitian yang dilakukan, diperoleh $\mathrm{F}_{\text {hitung }}=3,929$ dan $\mathrm{F}_{\text {tabel }}=3,11$ karena $\mathrm{F}_{\text {hitung }}>\mathrm{F}_{\text {tabel. }}$ Dan tingkat signifikan $<$ 0,05 , yaitu $0,001<0,05$ maka Hipotesis diterima, sehingga dapat disimpulkan bahwa Komitmen Organisasi (X1) dan Penempatan kerja (X2) berpengaruh secara simultan terhadap Kinerja Karyawan pada Kantor Badan Pusat Statistik Provinsi Sumatera Utara.

DAFTAR PUSTAKA

Adiftiya, Jajang. 2014. Pengaruh Komitmen Organisasi Terhadap Kinerja Karyawan Pada PT.
Bukit Makmur Mandiri Utama Site Kideco Jaya AgungBatu Kajang Kabupaten Paser. eJournal Ilmu Administrasi Bisnis ISSN 2355-5408. Vol. 2 Nomor 4. Halaman 833-845.

Arikunto, Suharsini. 2006. Prosedur Penelitian. Edisi Revisi. Yogyakarta: PT. Rineka Cipta

Arsiyati, 2013. Pengaruh Komitmen Organisasi, Kepuasan Kerja dan Stres Kerja Terhadap Kinerja Karyawan AJB BUMI PUTRA Cabang Ngawi. Jurnal Ilmiah STKIP PGRI Ngawi. ISSN 2356-2692. Vol. XI Nomor 1. Halaman 87-95.

Bernardin \& Russel,. 2006. Pinter Manajer, Aneka Pandangan Kontemporer. Alih Bahasa Agus Maulana. Jakarta. Binarupa Aksara

Dessler, Gary. 2004. Human Resource Mangement. Ninth Edition. New Delhi: PrenticeHall

Djaali dan Muljono, P. 2007. Pengukuran Dalam Bidang Pendidikan. Jakarta. Grasindo

Hammed, A., \& Waheed, A. (2011). Employed Development and its affect on employee performance a conceptual framework. International journal of business and social science., ISSN 23552678. Vol. 2 Nomor 13. Halaman 224-230.

Hasibuan, Malayu, S.P. 2005. Manajemen Sumber Daya Manusia. Jakarta: PT. Bumi Aksara

Kalesaran.Hendrik.Frans, Mandey.L.Silvya, Mekel.A.Peggy. (2014).Pengaruh Motivasi, Penempatan Kerja, Dan 
Pengembangan Karir Terhadap Kinerja Pegawai Pada Badan Lingkungan Hidup Provinsi Sulawesi Utara. Jurnal EMBA. ISSN 2303-1174. Vol.2 Nomor 4. Halaman 184-194.

Kuncoro, Mudrajad. 2013. Metode Riset Untuk Bisnis \& Ekonomi. Jakarta. ErlanggaLukman. Nazmi Sarah, dan Adolfina. 2015. Analisis Lingkungan Kerja, Komitmen Organisasional, Dan Kompensasi Terhadap Kinerja Karyawan PadaPT. Bank Sulut Manado. Jurnal Fakultas Ekonomi, Universitas Sam Ratulangi Manado. ISSN 23555408. Vol. 3 Nomor 4. Halaman 343-367.

Luthans, Fred. 2006. Perilaku Organisasi (Alih Bahasa V.A. Yuwono, dkk. Yogyakarya. ANDI

Mangkunegara, A.A Anwar Prabu, 2009. Manajemen Sumber Daya Manusia. Bandung: PT. Remaja Rosdakarya

Mangkuprawira, Tb. Sjafari. 2005. Manajemen Sumber Daya Manusia Strategik. Jakarta; PT. Ghalia Indonesia

Mathis Robert L. dan Jackson John H. 2006. Human Resource Management. Jakarta. Salemba Empat

2009. Human

Resource Management. Jakarta. Salemba Empat

Moeheriono. 2009. Pengukuran Kinerja Berbasis Kompetensi. Bogor: Ghalia Indonesia

Ridwan. 2007. Skala Pengukuran Variabel-Variabel Penelitian. Bandung: Alfabeta
Rivai, Veithzal. 2005. Manajemen Sumber Daya Manusia Untuk Perusahaan, dari Teori ke Praktik. Jakarta: PT. Raja Grafindo Persada 2008. Manajemen Sumber Daya Manusia Untuk Perusahaan, dari Teori ke Praktik. Jakarta: PT. Raja Grafindo Persada

Robbins, S dan Coulter,M. 2007. Manajemen, Edisi Kedelapan, Jakarta. Penerbit PT. Indeks

Robbin. SP, dan Judge. 2008. Perilaku Organisasi. Jakarta. Salemba Empat

Runtunuwu, Hiskia Jones. Lapian, Joice. Dotulong, Lucky. 2015. Pengaruh Disiplin, Penempatan Dan Lingkungan Kerja Terhadap Kinerja Pegawai Pada Badan Pelayanan Perizinan Terpadu Kota Manado. Jurnal Fakultas Ekonomi, Universitas Sam Ratulangi Manado. ISSN 23555408. Vol. 1 Nomor 5. Halaman 313-347.

Sastrohadisuwiryo, B. Siswanto. 2003. Manjemen Tenaga Kerja Indonesia, Jakarta: PT. Bumi Aksara

Siagian, Sondang, P. 2004. Teori Motivasi dan Aplikasinya. Jakarta: PT. Rineka Cipta

Sinambela, Lijan. 2012. Kinerja Pegawai ; Teori, Pengukuran, dan Implikasi. Yogyakarta. Graha Ilmu

Soekidjan, Sugiarto. 2009. Sp. KJ. Komitmen Organisasi Sudahkah Menjadi bagian Dari Kita

Sugiyono. 2008. Metode Penelitian Kuantitatif, Kialitatif, dan $R \& D$. Bandung. Alfabeta 
JURNAL PLANS

Penelitian Ilmu Manajemen \& Bisnis

ISSN: $1978-7057$

E-ISSN: 2527-306X

Umar, Husein. 2002. Riset Sumber Daya Manusia dalam Organisasi. Jakarta: Gramedia Pustaka

Wati. Eniza. 2013. Pengaruh Budaya Organisasi, Komitmen Organisasi Terhadap Hubungan Partisifasi Penyusunan Anggaran dengan Kinerja Pemerintah Daerah. Jurnal Fakultas Ekonomi Universitas Negeri Padang. ISSN 2155-5198. Vol. 2 Nomor 8. Halaman 213-247. 